PRESSING LAJOS

\title{
Az illúzió illúziója
}

(Buddhista gondolatok Sükösd Milós ökológiai médiakritikájához)

\section{Szerzői információ:}

Pressing L ajos

$\mathbf{R}$

Az ELTE-n végzett klinikai pszichológusként, 1979-ben ugyanott doktorált. 1987-ig az Országos Ideg- és Elmegyógyintézetben praktizált és végezett alkalmazott személyiséglélektani és pszichodiagnosztikai kutatásokat. A Kốrösi Csoma Sándor Buddhológiai Intézetben folytatott tanulmányokat követôen 1987-tôl két évig az Intézet tanáraként dolgozik, majd buddhista egyházi szolgálatba lép. 1997-ben a magyarországi Buddhista Misszió ügyvivôjévé választják. Az utóbbi 15 évben buddhista papi munkája mellett a keleti kultúrák és filozófiák témákörében publikál és tart előadásokat, tanfolyamokat.

E-mail: lilavajra@dakiniland.de

Így hivatkozzon erre a cikkre:

Pressing Lajos. „Az illúzió illúziója”.

Információs Társadalom IV, 3-4. szám (2004): 98-107.

https://dx.doi.org/10.22503/inftars.IV.2004.3-4.14

A folyóiratban közölt müvek

a Creative Commons Nevezd meg! - Ne add el! - Így add tovább! 4.0

Nemzetközi Licenc feltételeinek megfelelően használhatók. 
Pressing $\mathrm{L}$ ajos

Az illúzió illúziója

Buddhista gondolatok Sükösd Miklós ökológiai

médiakritikájához

Sükösd Miklós „Totális medialitás és ökocídium” (Információs Társadalom, 2003. III. évf. 3-4 sz., pp. 131-146.) címû tanulmányában megrázó helyzetképet fest a fogyasztói társadalom két pregnáns aspektusának, a természeti környezet pusztításának és a társadalom médiával való átitatottságának kapcsolatáról. Jóllehet Sükösd egyes kritikusai e két látszólag távoli jelenségcsoport létét, illetve súlyosságát is kétségbe vonják, az igazán új, s talán leginkább vitatott gondolat a szerző megállapításai között az, hogy ezek között oksági kapcsolatot igyekszik kimutatni.

A cikk körül kialakult szakmai vitához csupán laikus olvasóként tudok hozzászólni, de ha már megkérdeztek, néhány szubjektív megjegyzés ezzel kapcsolatban is kikívánkozik belőlem. A vitázók egyik szekértáborát alkotó társadalomtudósok bírálatában meggyôzốek azok az érvek, amelyek a vizsgált jelenségek komplexitásához képest Sükösd gondolatmenetének túlzottan leegyszerúsítő jellegét kérik számon. A média a modern társadalomnak csak egyik aspektusa vagy alrendszere, míg a természetrombolás a társadalmi-történeti komplexum egészének egyik legfenyegetőbb outputja. Ezért ha a medialitás outputra gyakorolt hatásáról érvényes kijelentéseket akarunk tenni, akkor nem hagyhatjuk figyelmen kívül a médiának a társadalmi-gazdasági rendszer egészéhez és egyéb alrendszerekhez füződő viszonyait. Tudományos oldalról a média differenciáltabb szemlélete iránti igény is jogosnak tûnik.

Egy rövid tanulmány azonban nem léphet fel e kérdések teljes komplexitásukban történő vizsgálatának igényével, és bevezetőjében maga Sükösd is kijelöli hipotézise szûkebb vonatkoztatási kereteit. Mint olvasó, a tanulmány körül kibontakozó vitától részben éppen azt vártam volna, hogy továbbgondolja és kontextusba helyezve is megvizsgálja Sükösd rendkívül érdekes téziseit. Sükösd érvelése tudományos értelemben talán nem bizonyító erejû, ahhoz azonban eléggé fajsúlyos és elgondolkodtató, hogy legalábbis mint heurisztikát komolyan vegyük. Sajnálatos, hogy bírálói az érdemi vizsgálat helyett - Boda Zsolt pártatlan és valóban színvonalas elemzését kivéve - egyszerúen lesöprik azt az asztalról. A helyből történő éles elutasítást még az sem indokolja, ha a szerző a tudományos publikációk etikettjét némileg lazán kezelve az esszéisztikus stílusnak tesz engedményeket. Alighanem igaza van Takács-Sánta Andrásnak, amikor úgy véli, hogy itt valójában világnézetek, értékrendek csapnak össze.

Ez persze nem teszi értelmetlenné a vitát, csak áthelyezi annak súlypontjait. Az értékrendek ütköztetése nagyon is fontos lehet, amikor valamennyiünk jelenéről és jövőjérôl van szó. Mert ha igaza van is $Z$. Karvalics Lászlónak abban, hogy ember által előidézett ökológiai válság és környezetpusztítás az iparosodást megelőző korokban is előfordult, a jelenlegi ökológiai válság ezektôl globális jellegét illetően mégiscsak alapvetôen különbözik. Bizonyos problémákat gazdasági és katonai eszközökkel ideig-óráig (egyelőre még) át lehet terhelni a fejlődő országokra, a Nagy-Britanniát szájés körömfájás járvánnyal elfertôző szaharai homokfelhőt, a klímaváltozás következtében fellépô elsivatagosodást és orkánokat, a nukleáris és olajtechnológiai katasztrófák következményeit nem lehet az országhatárokon kívül tartani. A mai válságot nem le- 
het elvándorlással, új termôterületek feltárásával vagy új technológiák kifejlesztésével megoldani. Elvándorolni nincs hová, az emberi életnek pedig vannak olyan biológiai és lélektani - mondjuk így: természeti - elôfeltételei, amelyek technológiai úton nem pótolhatók. Vagy ha mégis, és komolyan vehetố alternatívának tekintjük azt az egyes technofanatikusok által propagált és sajnos magasan finanszírozott kutatási projektekben is testet öltô rémálmot, amely az embert húsgép alapú információfeldolgozó rendszerként kezelve a teljesen mesterséges táplálás és reprodukálás felé vesz irányt, nos, akkor a tápsó-oldatok, a spermainjekciók, a tápszer- és vitamin-pirulák, a mesterséges napfény és a neurocsipek mellett bizonyosan szükség lesz olyan mesterségesen gerjesztett élmény- és gondolatvilágra is, amely a létünk természeti alapjába való szerves és bensőséges beágyazódás lélektani alapszükségletét kiváltja.

Ebből a perspektívából nézve a Mátrix negatív utópiája nem is olyan képtelenség, legfeljebb a szórakoztatóipar igényeinek megfelelően kissé primitíven van megfogalmazva. Ha azonban megnézzük jelenlegi helyzetünket - a vegyipari és géntechnológiai alapú földmúvelést, az ipari hústermelést, a mesterséges táplálékkiegészítők, gyógyszerek és ipari adalékok fogyasztását, a saját testünkhöz való viszonynak a születéssel kezdôdô és a halál utáni boncolással és ipari feldolgozással végzôdô áttechnicizáltságát, az élő természettel való kapcsolat visszaszorulását, a természeti tér aggasztó zsugorodását és az életformák gazdagságának pusztulását, 'az ipari termékeknek az emberi élettérben elfoglalt igen magas arányát - , akkor legalábbis számot kell vetnünk a lehetôséggel, hogy a saját természeti gyökereinkkel való kapcsolatunk az átlagember szintjén esetleg már most is visszavonhatatlanul megbomlott. Ebben az esetben pedig a médiának nemcsak az lehet a funkciója, hogy politikai és gazdasági érdekeket juttasson érvényre, vagy önmaga által gerjesztett igényeket elégítsen ki, hanem fogyasztását bizonyos alapvetô lélektani szükségletek, hiányállapotok is motiválhatják. Amikor a média, pl. az Internet használata függôségi betegség formáját ölti, mindig kimutathatóak olyan alapvetô - legtöbbször az intim és szociális kapcsolatok terén jelentkezô - lélektani megoldatlanságok, amelyeket a beteg a reális szinten hozzájuk kapcsolódó szorongás miatt nem képes kezelni. A média virtuális világa ilyenkor kompenzatorikus menekülési útvonalat és részleges - látszólagos - szükséglet-kielégítést kínál, ami legalábbis elkerülhetôvé teszi a problémával való nyílt konfrontációt. Honnan tekintjük azonban a média fogyasztását kóros függőségnek? Ez éppúgy definíció kérdése, mint az, hogy mikortól tekintjük kóros függőségnek a cigarettázást. Ha léteznek olyan, a modern világban általánosan kielégítetlen lélektani alapszükségletek és megoldatlanságok, amelyek médiafogyasztásra ösztönzik az embereket, akkor Sükösd hipotézise már nem is látszik annyira abszurdnak. Mint ahogy a kábítószer is konzerválja és elmélyíti azokat a problémákat, amelyek elől menekülve a függố személy a drogra rászokott, a médiáról sem lehetetlen - legalábbis bizonyos aspektusában - a természetpusztítást, a civilizációs szorongást és természetesen egyéb szorongató társadalmi problémákat is önmagunk elől „álcázó” társadalomlélektani elhárító mechanizmusként, egyfajta „elektronikus drogként” gondolkodni.

Teljesen egyetértek a társadalomtudósokkal abban, hogy a média sokarcú és összetett jelenség, s a Sükösd írásában felvetett gondolatok annak csupán egy részaspektusát érinthetik, ennél többet azonban maga a szerző sem állít. Annyit azonban megérdemelne ez a hipotézis, hogy komolyan megvizsgáljuk, melyek a média fogyasztását motiváló lélektani tényezôk, s hogyan hat vissza mindez az ember valóságérzé- 
kelésére? A probléma egyik nehézsége, hogy az elkerülő és szorongásos hátterû motivációk empirikusan nehezen mérhetôk, mivel ezeket természetük szerint az emberek kiszorítani igyekeznek a tudatos önreflexió körébôl. A médiában dolgozó magas beosztású barátom említette egyszer azt a megfigyelését, hogy a rádiót és televíziót a horror vacui múködteti. Ez az izgága nyugtalanság azonban nem biztos, hogy a média alkotóinak neurotikus szorongása; könnyen meglehet, hogy ők is csak a néző „ürességtôl való rettegését" anticipálják szakmájukból fakadó érzékenységgel. Végsố választ talán csak az adhatna, ha mondjuk egy-két hétre hirtelen kikapcsolnának minden médiát, s megfigyelhetnénk, mihez kezdenének az emberek az így felszabadult „üres” idôvel?

Ha már heurisztikában gondolkodunk, a vita több megszólalójához hasonlóan én sem tudok eltekinteni a témával kapcsolatos meghatározó személyes élményeimtôl. A média fejlődésével szinte együtt nőttem fel, a vezetékes néprádiótól a városkában található összesen három fekete-fehér televízión keresztül egészen addig, amíg minden háztartásnak nélkülözhetetlen kellékévé nem vált a színes TV. Saját bőrömön tapasztaltam, hogyan szorította ki egyre inkább e vidéki környezetben a televízió a korábbi szerves és intenzív rokoni és baráti kapcsolatokat, együttléteket. A természeti környezet pusztulását és elszennyeződését gyermekkori emlékeimhez mérem. Nyilván ízlés és értékrend kérdése, mennyiben kárpótol valakit mindezért az, hogy a bevásárlóvárosok pultjain diszkréten édeskés zenére márkajelzéssel ellátott cuccok között turkálhat. A változás üteme azonban, amit mind a technológiai és életmódbeli átalakulás, mind a természet pusztulása oldalán alig fél évszázad alatt átéltem, mindenképpen megdöbbentő, ijesztő és figyelmeztető.

Néha az az érzésem, mintha kortársaim többsége, akiknek mindez fel sem tûnik, elvesztette volna az emlékezetét. Zárójelbe téve ez felvet egy Sükösd által nem említett, de gondolatmenetébe nagyon is illeszkedő munkahipotézist: vajon hogyan befolyásolja az emberek tudatát átitató medialitás a múlthoz és emlékeikhez való viszonyukat? A múlt érzelmi és értékrendbeli devalválása ugyan nem médiasajátosság, hiszen a rövidülő technológiai megújulási ciklusok és a divat marketingszerepe a fogyasztói társadalom lényegévé teszik az újdonságokra és az aktualitásra irányuló szinte kizárólagos figyelmet. Termékeinek rendkívül rövid életciklusával azonban, figyelembe véve a fogyasztásával eltöltött jelentốs idôt is, a múlthoz való attitûd áthangolásában is kiemelt jelentősége lehet a médiának. Hiszen a tartalomelemző kutatók kivételével ki olvas tegnapi vagy múlt heti újságot, nem is beszélve a TV-nézésrôl vagy rádióhallgatásról, melynek médiumai mûfajilag is tulajdonképpen csak jelen idôben (a músorsugárzás folyamatában) értelmezhetők? Bármilyen szintû valóság legyen is számunkra a mûsor, a vele kapcsolatos élmények naponként ismétlődő, folyamatos és gyors kisöprése a tudatból már csak tanuláslélektani törvényszerûségek okán is kell, hogy kondicionálja bizonyos mértékben az élményeink megôrzésével és azok érzelmi utóhatásával kapcsolatos pszichés folyamatokat.

A média és a természetben való lét eltérô valóságszintjével kapcsolatban úgy tưnik, mintha bírálói nem értették, vagy nem akarták volna megérteni Sükösd mondanivalóját. Ezt a félreértést az okozhatja, hogy az élményt implicit módon az abban foglalt információval azonosítják. Az élménynek azonban információtartalmán kívül számos egyéb komponense is van, amit a média nem tud közvetíteni. Nem valószínú, hogy a farmer vagy szállodatulajdonos, akinek a floridai vagy portugáliai erdôtüzek ép- 
pen elérik a telekhatárát, ugyanazt a valóságot tapasztalja, mint az, aki karosszékből nézi a TV-ben az erről szóló híreket. Magam is a médiából informálódom évtizedek óta a fejlődő országok problémáiról, sốt erre vonatkozóan néhány statisztikai adatot is ismerek. Néhány év óta azonban, mióta alkalmam volt ebból egy harmadik világbeli országban helyszíni ízelítőt kapni, megértettem, hogy e kétfajta tudás mily áthidalhatatlan távolságban van egymástól. Az úgynevezett „kultúrsokkot” - a harmadik világba utazó „újoncok” e tipikus élményét - nem a nyugatitól gyökeresen eltérô kultúrával való találkozás, hanem a nyomornak, a népsưrűségnek és a nyugati technológiákon keresztül importált szeméthegyeknek és környezetszennyezésnek informatíve ugyan ismert, a „valóságos” élmény szintjén mégis elképzelhetetlen mértéke váltja ki. Az ökológiai válságról továbbított médiainformációk részben ismertté teszik ugyan az erre vonatkozó tényeket, másrészt a közvetlen élménytől való eltávolítással egyben relativizálják is azokat. Az ózonlyuk tágulásáról szóló riasztó hírekrôl ma már mindenki tud, de vajon az emberek hány százaléka cserél emiatt hútőszekrényt, vizsgálja meg az általa vásárolt spray hajtógázának összetételét, módosítja fogyasztói vagy utazási szokásait?

Sükösd opponensei egyszerre hivatkoznak a médiát is szervesen magában foglaló „egyetlen valóságra” és a médiakörnyezet sokféleségére, amikor vitatják a valóságos környezet és a médiakörnyezet megkülönböztethetőségét. De meg tudunk-e egyezni abban, vajon melyik kinyilatkoztatás „egyetlen valóságát” fogadjuk el valamennyien, amikor a modern fizika már anyagi szinten is parallel valóságok létezésével számol? Ha már egy szubatomi részecske helyzete és tulajdonságai sem állapíthatók meg a megfigyelôtổl és annak módszerétôl függetlenül, mennyivel inkább így van ez a társadalmi folyamatokkal, melyeknek a vizsgált populáció szubjektumai éppúgy elválaszthatatlan részét alkotják, mint maga a kutató és annak kérdésfeltevése? Valóságról csak ott lehet beszélni, ahol azt valaki ténylegesen tapasztalja, ez pedig mindig elkerülhetetlenül személyes és szubjektív. Pszichológusként inkább úgy látom, hogy nem egy, hanem mérhetetlenül sokféle valóság létezik: bizonyos értelemben minden tudatos lény más-más világban él, sổ nem is egy, hanem számos valóságnak részese egyszerre, melyekben eltérô attitûdök, viselkedési szabályok, értelmezések, élménymodalitások és tartalmak lehetnek érvényesek. E valóságok áthatják és részben fedik egymást, más tekintetben különböznek; vannak olyan vonásaik, amelyek nagy tömegeknél bizonyos hasonlóságokat mutatnak - és éppen ezáltal társadalomtudományi módszerekkel statisztikailag absztrahálhatók - , de mindig akadnak mindenféle szabály alól kibúvó teljesen individuális, statisztikai értelemben deviáns valóságok is. Alig hiszem, hogy a megszólaló szociológusok vagy médiakutatók közül bárki is közölni tudna tudományterületérôl másfajta, mint legfeljebb statisztikai érvényú igazságokat. Ezért az, hogy a média fogyasztásában és a médiaélmény jellegében is számtalan egyéni változat létezik, nem csökkenti Sükösd megállapításainak potenciális érvényét.

Igenis feltehető tehát a Sükösd hipotézisének alapjául szolgáló kérdés, hogy van-e az amúgy igen változatos médiakörnyezeteknek olyan közös, statisztikailag az esetek jelentős részében előforduló vonása, ami jellemzố módon különbözik a nem mediális környezetben történő megismerés statisztikailag gyakori tulajdonságaitól? Elemzését lényegében Sükösd is ilyen valószínűsíthetô különbözőségekre - pl. a mediális megismerések közvetítettségére, külsô szerkesztettségére és értelmezettsé- 
gére, fiktív jellegére stb. - építi. Az egyén lélektana szempontjából pedig a legváltozatosabb médiakörnyezetekben és a nem mediális környezetekben történő megismerések között még erôsebb különbségeket találunk:

(i) Az Internettôl a televízióig, a sajtótól a rádióig valamennyi mediális megismerési környezetet az érzékszervi csatornák erős minőségi beszúkülése és mennyiségi redukciója jellemzi. Szemben a nem mediális megismerés leképezésével, melyben túlnyomórészt hat csatorna (látás, hallás, tapintás+propriocepció, ízlelés, szaglás és fogalmi gondolkodás) játszik szerepet, a médiakörnyezetet a legjobb esetben is legfeljebb háromcsatornás leképezés jellemzi. A hétköznapi valóságnak olyan lényeges összetevői, mint a szag, az íz vagy a tapintás, kivétel nélkül minden médiakörnyezetbôl hiányoznak. (ii) A használt érzékelési csatornák terjedelme is beszúkül, fokuszálódik és a nem mediális elemek iránti fogékonyság lecsökken (képernyőre, olvasmányra, hangforrásra történő fokuszálás). (iii) A mediális környezetben radikálisan csökken a mozgásos aktivitás, ami pszichológiailag megváltoztatja az érzékelés minőségét. Ez még az egyébként interaktív médiára is igaz, hiszen az interaktivitás csak egy igen körülhatárolt csatornán valósul meg. (iv) A médiára irányuló figyelem csökkenti a párhuzamosan folyó hétköznapi történésben való figyelmes jelenlét hatásfokát és intenzitását. A figyelem terjedelme ugyanis korlátozott, s amilyen mértékben lefoglalja azt a médiakörnyezet, olyan mértékben csökken a hétköznapi - persze nemcsak természeti, hanem éppúgy az ember alkotta és a társas - környezetre jutó figyelem. Ha valaki ebben kételkedik, akkor próbáljon meg valamilyen nagyfokú odafigyelést igénylő nem mediális tevékenységet, mondjuk egy szeretkezést végrehajtani úgy, hogy közben értő figyelemmel követi a TV-híradót. (v) Jóllehet a médiakörnyezetek jelentôs részében előfordulnak érzéki elemek, a hétköznapi észleléstôl eltérően ezek valójában csak reprezentációk, s nem önmagukat jelentik. A futballmeccs TV-közvetítésének vizuális képei nem a képernyôn kirajzolódó síkbeli grafikus formákat, hanem a távoli stadionban zajló hús-vér szereplők jóval tágabb térben végbemenő összecsapását közvetítik. Még ha e reprezentációk és az általuk közvetített események között van is formai hasonlóság, e megismerés pszichológiai természete sokkal közelebb áll az ugyancsak reprezentációkon alapuló gondolati, mint az érzéki megismeréshez.

Elmondható tehát, hogy a média valósága a gondolathoz hasonlóan reprezentációkból álló valóság - ami nem a média igazságtartalmát minôsíti, hiszen információtartalmát tekintve elvileg ez is bármilyen igazságkritériumnak megfelelhet -, hanem a közvetlen érzékszervi megismeréstôl való távolságát. A média azonban a gondolkodástól eltérôen olyan csatornákat foglal le a reprezentáció céljára, amelyek amúgy a normális érzékszervi tapasztalás célját szolgálnak, így azok természetes funkciójával, a közönséges érzéki valóság megismerésével szükségképpen interferál. Ez olykor még a mediális reprezentáció céljára leginkább használt érzéki csatornák szervi degenerálódásához is vezethet (lásd pl. a walkman-használattal összefüggő halláskárosodások megszaporodását a fiatalabb korosztályokban).

Voltaképpen az emberi megismerésben is vannak olyan pszichés reprezentációk, amelyek a külön leképezési szintet képviselő gondolattól eltérốen ugyancsak egyes érzéki csatornák tartalmait, elsősorban éppen a látási és hallási formákat használják: ilyenek a fantázia, az ábránd, a képzelet és az álom. Pszichológiailag tehát teljesen releváns a média és a fantázia között kapcsolatot keresni, és amennyiben ilyet 
találunk, a média által képviselt valóságszintet az érzéki megismeréssel szemben inkább a képzelet valóságszintjéhez hasonlítani. Bizonyos értelemben a vizuális média felfogható úgy, mint objektiválódott és társadalmivá lett képzeleti funkció, mint ahogy az írott média is lényegében külsôvé vált és társadalmiasodott gondolat. Hogy miképp befolyásolja a képzeleti funkció ilyetén „kihelyezôdése” az emberi megismerést, személyiséget, társas alkalmazkodást, emocionalitást és attitûdöket, vagy akár a természethez való viszonyt, úgy vélem, legitim és indokolt tárgya lehet a tudományos kutatásnak, és megalapozottá teszi Sükösd kérdésfeltevését.

A fenti észrevételek azokat az elsố gondolatokat foglalják össze, amelyeket ennek az igen érdekes vitaanyagnak az olvasása ébresztett bennem. Miután azonban a vitának kialakult egy vallási-teológiai vonulata is, s a hozzászólásra tulajdonképpen errôl az oldalról - a buddhista nézôpont megismertetése érdekében - kértek fel, néhány gondolat erejéig szeretném kicsit más irányból is megközelíteni a kérdést.

Előzetesen azonban szeretném megnyugtatni a vita minden résztvevőjét, hogy én sem kívánkozom vissza a kőkorszakba, aktívan használom az Internetet, és nem hiszek abban, hogy az ökológiai probléma megoldását a korábbi technológiák szintjére, netán a gyưjtögető-pecázó életformához vagy a nomád állattartáshoz való visszatérés jelenthetné. Márcsak azért sem, mert ebben az esetben óhatatlanul szembe kellene nézni a kérdéssel, hogy a 6 milliárdból melyik legyen az az öt és fél, amelynek eltartása ezekkel a módszerekkel nem biztosítható, továbbá hogyan történjen a likvidálásuk. Meg vagyok győződve arról, hogy az ökológiai problémák kezelésére a mai helyzetben az emberiségnek már valóban csak új, környezetkonformabb technológiákra való átállással, és nem a technológia visszafejlesztésével lehet esélye.

Mindez nem hatálytalanítja korábbi megjegyzésemet, amelyben szkepszisemet fogalmaztam meg azzal a gyakran hallott önnyugtatgató véleménnyel szemben, hogy a technikai fejlődés mintegy magától megoldja majd az ökológiai krízis által felvetett problémákat. Nézetem szerint ugyanis az ökológiai krízis mélyebb oka nem az azt közvetlenül elôidézố technikai fejlődésben, nem az iparban - és természetesen nem is a médiában - keresendő, hanem bizonyos emberi attitüdökben és motivációkban, és az ezek által mozgatott társadalmi tevékenységekben. Az ipari tevékenység és a technika mai formájában csupán megjeleníti és érvényre juttatja ezeket az emberi késztetéseket és törekvéseket. Éppen ezért érdemi változás is csak az emberi attitûdök és motivációk szintjén következhet be. Ez odáig terjed, hogy ennek hiányában a részben már ma is létezố környezetbarát technológiák elterjedésének sincs esélye. A fogyasztói társadalomban meghatározó értékek és célok, pl. a maximális profit, minél nagyobb fizetés, kényelem, olcsó és tömeges előállíthatóság, a jelenlegi divatokhoz és fogyasztási szokásokhoz való illeszkedés, katonai hatékonyság stb. szempontjából ugyanis a környezetbarát technológiák nem versenyképesek, és elvileg sem lehetnek azok. Az ökológiai krízisben szerepet játszó technológiák versenyképességének forrása ugyanis jelentôs részben a gazdasági mérlegben nem, vagy nem reális súlyának megfelelően feltüntetett - részben még nem is teljesen ismert vagy elismert - környezetkizsákmányolás. A technológiai megújulásnak előfeltétele a fogyasztói társadalmat jellemzô értékrend és attitûdök, s ebból következôleg a gazdaságot szabályozó mechanizmusok gyökeres átalakítása. Amint Gandhi mondja egyhelyütt: „A Föld eleget terem ahhoz, hogy kielégitse minden ember szükségletét, ám nem minden ember mohóságát.” És ezen a ponton érkezünk el a buddhizmushoz. 
Személy szerint engem a buddhizmusban éppen azok a tiszta és több mint kétezer évesen is meghökkentően modern gondolatok ragadtak meg, amelyek ma is világos kiutat kínálnak az ember önmaga által elôidézett szenvedéséből és fenyegetettségéből. A buddhizmus alapeszméje és lényege, amit „szabadságnak” nevez, a tudatos létezésből következő felelősség önmagunkért, cselekedeteinkért, életünkért, de egyben környezetünkért, minden más lényért, sốt a világ egészéért. A buddhizmus világképében a hangsúly nem valamiféle transzcendens teológián van, hanem az ember és az általa teremtett valóság viszonyán. A buddhizmus szemlélete voltaképpen lényege szerint mélyen ökológiai, ami nemcsak az ember saját felelősségének hangsúlyozásában, hanem a minden létezô egymástól való kölcsönös függésének és egymásba ágyazottságának tanában, és az ebből következố egészleges, a létezés teljességének érdekeit szem előtt tartó értékrendjében is megnyilvánul.

$\mathrm{Az}$ emberi szenvedést, illetve az emberi tudat és a létezés közötti harmónia megbomlását a buddhista bölcselet bizonyos tudati elszennyeződésekre, úgynevezett gyökérokokra vezeti vissza. Az ökológiai krízis maga is a környezettel való harmónia emberi tevékenység által előidézett megbomlása, mely hosszú távon magát az emberi létet veszélyezteti, számos más lényt már jelenleg is súlyos szenvedéssel sújt. Az ökológiai problémák tehát tudati szinten ugyanezekból a gyökérokokból fakadnak.

A végső és legalapvetốbb gyökérokot a buddhizmus az emberi tudás tökéletlenségében - félrevezetô, önáltató, illúziókba merülő - természetében látja. A megismerést eluraló „hamistudat” vagy „káprázat” következtében a boldogság, elégedettség, biztonság iránti vágy normális késztetéseit következetesen téves, hosszú távon inkább szenvedéshez és konfliktusokhoz vezetô módokon igyekszünk kielégíteni. A legsúlyosabb káprázatnak a buddhista tan éppen azt tartja, amikor tényleges szabadságunkról és az életünk alakításáért viselt felelôsségünkrôl nem veszünk tudomást. Buddhista szempontból minden, akár csak részlegesen is determinista felfogás - akár vallási, akár történelmi vagy társadalomtudományi mezben jelenik meg - erre az alapvető hamistudatra épül. Ez nem azt jelenti, mintha a buddhizmus vitatná a tudományos megállapítások viszonylagos érvényét: ha ugyanis az ember önmaga determináltságának és felelőssége elhárításának tudatában él, akkor tudatos létéből fakadó elvi választási szabadságát elmulasztja realizálni. Ennek mértékében aztán valóban külső környezete és saját spontán ösztönzései által determinálttá válik. Buddhista szempontból az emberi problémák tartós megoldásához vezetô egyetlen reális alternatíva a szabadság megértésén és az ehhez tartozó globális felelősség felvállalásán, vagyis az ember felnőtt, autonóm döntésekre képes és tudatos lénnyé történő emancipálásán keresztül vezet. Minden olyan tényezôt, amely az ez irányú fejlődést elősegíti, a buddhizmus etikailag és spirituálisan kedvezőnek értékel, s mindent, ami akadályozza ezt, s az embereket determinált és manipulálható állapotban, függőségben és illúziók között tartja, a szenvedés és degenerálódás forrásának tekinti.

Ez az alapelv már önmagában is kiindulópontjául szolgálhat a média buddhista szempontú értékelésének - akár szorosan az ökológiai probléma vetületében is -, és nyilvánvaló, hogy mind a különféle médiumok összehasonlításában, mind egyazon médiatípuson belül a média hatásának differenciált megítélését igényli. Minden médiumnak, még a televíziónak is vannak olyan hatásai, amelyek elősegítik az emberek emancipálódását és autonómiáját; ilyenek például az oktató és nevelő hatású programok és a felelős döntésekhez nélkülözhetetlen információk továbbítása. Más kérdés, 
hogy ha ezek arányát a manipulatív, szórakoztató - etikai értelemben tompító hatású -, függőségeket és negatív ösztönzéseket erôsítő, egyszóval illúziókat továbbító programokhoz viszonyítjuk, akkor Sükösd tanulmányának negatív kicsengésú minôsítése nagyon is indokolt lehet. A Székely Mózes által bemutatott statisztikák meggyőzően mutatják, mennyire tendenciózusan torzítóak még a médiában közölt híranyagok is. Nem zárható ki ugyanakkor, hogy ebben a tekintetben a jóval kevésbé szelektív és jellegénél fogva „demokratikusabb” Internet lényegesen eltérô képet mutat.

A tudásdeficitnek vagy káprázatnak persze még sok más szimptómája is van, melyek közül a jelen téma összefüggésében az ún. „én-illúzió” lehet releváns. Én-illúziónak a buddhista doktrína azt a hamistudatot nevezi, mely a saját személyiséget a környezettől függetlenül létezô, zárt és izolált, önmagában adott entitásnak mutatja. Az én-illúzió következménye az a modern fogyasztói kultúrát erősen jellemző alapattitûd, mely a saját személy boldogulását, élvezeteit, érvényesülését, önkifejezését természeti világa, sốt saját szélesebb társadalma szükségleteinek figyelmen kívül hagyásával, vagy akár kifejezetten azzal szemben és annak rovására reméli megvalósítani. Az én-illúzióban nem a személyiség és annak valós szükségletei, hanem az én az, ami illuzórikus - a teljesség különböző létformáinak egymást feltételező valóságával szemben.

Az én-illúzióból további fontos gyökérszennyezốdések alakulnak ki, melyek közül itt talán két csoportot érdemes megemlíteni: az egyik a mohóság és a bírvágy, a másik pedig a diszkrimináció és az ellenszenv, a felülkerekedési vágy és az agresszió. Minthogy ezek az egoizmussal együtt a fogyasztói társadalom tulajdonképpeni legitim ösztönzéseinek számítanak, melyek a környezetpusztító és kizsákmányoló társadalmi gyakorlat fő motivációs mozgatói, feloldásuk, illetve átalakításuk a modern mentalitás és értékrend gyökeres megváltoztatását feltételezi. A buddhista elmélet szerint mind a túlzott fogyasztásra ösztönzô reklámok és egyéb mediálisan közvetített minták, mind pedig az agresszió és pusztítás mediális mintái erősítik a népességben az egoizmus-, mohóság- és gyưlölet-gyökerủ ösztönzéseket, s ezáltal közvetett módon valószínûsíthetôen hozzájárulnak az ökológiai válságot elmélyítô társadalmi gyakorlat fenntartásához. Érdemi változás ebben a gyakorlatban csak akkor várható, ha az értékrendben meghatározóvá a mértékletesség, az önkorlátozás, a tolerancia, az eltérő természeti és kulturális létformák iránti kifejezetten óvó és segítô, pozitív viszonyulás válik.

A hamistudatnak vagy káprázatnak buddhista értelmezés szerint van egy másik, mélyebb filozófiai alapvetés hiányában itt csak utalásszerüen érinthető aspektusa is, nevezetesen a jelenségek önmagában vett, szubsztanciális létezésének illúziója. A buddhizmus domináns, mahájána irányzata szerint a valóság természete végső értelemben „üres”, és azt a tudat értelmezései, illetve az értelmezésen keresztül a jelenségekkel létrehozott viszonylatai töltik meg tartalommal. Az „ürességre” vonatkozó tanítás a tudat végsố szabadságának másik, tárgyi oldala. Az élet éppen alapvetố „üressége” által tartja nyitva a lehetőséget a különféle értelmezések és ezen keresztül a különféle életgyakorlatok, sorsok előtt. Amennyiben a világot és benne önmagunkat adottnak, determináltnak, önmagában létezőnek látjuk, ez az önmagában - tehát a tapasztaló tudattól is függetlenként - történő észlelés a jelenségekben érzékelt „adottság” mértékében behatárolja a szabadság lehetőségeit. Ha például valaki a fogyasztói társadalmat történelmi szükségszerüségnek, az „emberi természet” következményének, vagy bármilyen más értelemben objektív adottságnak látja, akkor ezzel automatikusan lemond arról a szabadságáról, hogy azt saját választásain és valóság-értelmezésein keresztül alakítsa és megváltoztassa. 
A kora-középkori jógácsára bölcselete különböző valóságszinteket ír le. Az első a lét abszolút, feltétlen és végsố állapota (parinispanna) - az, ahogyan a dolgok tényleg vannak (tathatá). Ez a szubjektív oldalon a szabadság, a tárgyi oldalon pedig az üresség. A második valóságszintet a függő vagy relatív (paratantra) valóság képviseli: ez az, ahogyan a dolgokat a mindennapi életben érzékszerveinkkel és a bizonyos igazságkritériumok szerinti helyes gondolkodással érzékeljük. Ez végső értelemben ugyan nem igaz, mert hiányzik belőle a dolgok valódi természetére és a saját szabadságunkra vonatkozó tudás, feltételesen, viszonylagos módon azonban mégis van bizonyos valóságértéke, amennyiben megjelenik a tapasztalás tárgyaként, és belső összefüggései szerint bizonyos koherenciával és következetességgel rendelkezik. Mint neve is jelzi, ez a valóság bizonyos feltételek függvényében igaz, ám e feltételek nem abszolútak, s alakításukon keresztül maga a relatív valóság is megváltoztatható. A relatív valóság tapasztalásának például egyik lényeges feltételrendszere a nyelvi, társadalmi és kulturális konvenció, amely maga is változik, és részben tudatos társadalmi cselekvés révén változtatható. A valóság harmadik szintjét a jógácsára képzetesnek (parikalpita) nevezi: ez az olyan megismerésekre vonatkozik, amelyeknek semmiféle tényleges valósága nincs, vagyis még viszonylagos értelemben sem igazak. E filozófia megalkotói ennek paradigmájaként a spekulatív (a tapasztalattól elrugaszkodó, magukból a fogalmakból generált) fogalmi megismerést, illetve a képzelt vagy fiktív valóságot említik.

A relatív és a képzetes valóság között nem mindig könnyú különbséget tenni, mivel a képzetes valóság fikciói gyakran a mindennapi tapasztalatok értelmezése, vagy a mindennapi cselekvés explicit vagy implicit ideológiai alátámasztása formájában jelennek meg. Az emberek ezért hajlamosak azt összetéveszteni magával a tapasztalt (relatív vagy konvencionális értelemben igaz) valósággal. E képzetes valóság fiktív jellege azonban éppen fiktív volta miatt előbb-utóbb szükségszerúen lelepleződik, mert képzetessége pontosan azt jelenti, hogy valóságossá válásának feltételei még viszonylagos értelemben sem állnak fenn. A buddhizmus végsố értelemben a konvencionális vagy relatív valóságot is egyfajta káprázatnak tekinti, amennyiben az elrejti az ürességet, ill. a szabadságot, tehát a végső valóság természetét. A képzetes valóság viszont még ezt az elsődleges káprázatot sem tükrözi vagy reprezentálja hitelesen - a relatív valóság feltételeinek és belső logikájának megfelelően - , hanem arra egy minden reális alap nélküli, teljesen fiktív elképzelést vetít rá. Ha a mindennapi valóságunk végső értelemben egyfajta illúzió, akkor a képzetes valóság az a még mélyebb illúzió, amely félreismeri ennek az illúziónak a természetét.

Buddhista elemzés szerint az ember által előidézett problémák és szenvedések súlyossága az illúziók mélységével, tehát a tényleges valóságtól való elszakadás mértékével arányos. Jóllehet a relatív valóság is feszültségektôl és kielégületlenségektôl terhes - már csak egyik alapvető általános feltétele, nevezetesen mulandósága miatt is - , annak feltételeihez bizonyos fokig lehet alkalmazkodni, és viszonylagos, az adott feltételek által behatárolt harmónia vagy boldogság is létrehozható. A relatív valóságban folytatott élet nem üdvözült és nem végső értelemben boldog, de kisebb-nagyobb kompromisszumokkal élhetô. A fiktív valósághoz nem lehet alkalmazkodni, mert nem létezik, és létrejöttének feltételei sem valóságosak. Ezért a fiktív valóságra épített élet és társadalmi gyakorlat kizárólag súlyos diszharmóniákhoz és szenvedéshez vezethet. 
Ez a buddhista modell jól megvilágítja, miért vezettek a történelemben addig példa nélküli szenvedéstömeghez és emberi katasztrófához a gyakorlati megvalósítás kísérlete során éppen azok az újkori társadalmi utópiák, amelyek pedig mind a tökéletesebb társadalom és emberibb élet igézetével ragadták meg híveik képzeletét. Nem zárható ki, hogy az ökológiai krízis és az általa okozott szenvedés is a relatív valósággal való szembesülés olyan szimptómája, amely az azt előidéző társadalmi gyakorlat szellemi-ideológiai, tudományos-technikai, sốt politikai alapjainak fiktív és képzetes természetével szembesíti az emberiséget. Ha pedig ez tényleg így van, akkor a megsemmisítő katasztrófa csak a modern világnézet, a gazdaságfilozófia, a politika, a tudomány, az értékrend, valamint a nyílt és rejtett elképzelések és remények gyökerekig hatoló és kíméletlen kritikai önvizsgálatával kerülhetô el.

Ebből a szempontból a média szerepe is onnan ítélhetô meg, hogy milyen súlylyal jelenik meg benne a végsố valóságra ébresztő tanítás, a relatív élet igaz és hiteles bemutatása, illetve a fikció. Ha érvényes megállapításokat kívánunk tenni, nyilván itt is differenciáltan kell megvizsgálni a különböző médiumokat, múfajokat stb. Ha azonban az emberek által legtöbbet fogyasztott médiában elsöprő túlsúlyba kerül a fikció, a relatív valóság közvetítését pedig az uralkodó értékrend, politikai hatalom és gazdasági befolyásoló tényezốk - vagy éppen a szerkesztốk vagy médiaguruk saját fiktív elképzelései - nagymértékben manipulálják, akkor a Sükösd tanulmánya által megfogalmazott negatív hipotézis megalapozott lehet; annyiban legalábbis feltétlenül, hogy indokolttá tegye az alaposabb vizsgálatokat. Ez a média önismerete és a fejlődésével szemben támasztott társadalmi elvárások megfogalmazása szempontjából is elengedhetetlen ahhoz, hogy az általa létrehozott reprezentáció ne csak az illúzió egyfajta illúziója legyen, mely a modern élet utat tévesztettségének és ürességének ijesztő tényét takarja. 